\title{
スピンプローブ法と示差走查熱量分析法による合成二分子膜 およびリン脂質二分子膜の機能評価
}

（1982 年 6 月 21 日受理）

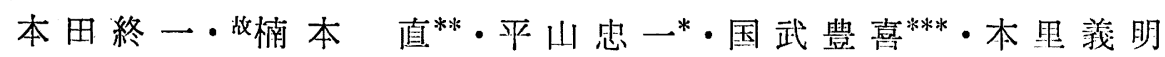

極性基とアルキル鎖長の異なった合成二分子膜およびリン脂質二分子膜について，ゲルー液晶相転移 温度での吸熱量, アルキル鎖部分の運動性および基質の取り込みの相違を示差走査熱量分析法とスピン プローブ法を用いて検討した。またコレステロールを二分子膜に混入させた場合の物性変化についても 検討した。示差走香熱量分析法により，アンモニウム塩, リン酸塩, コハク酸塩型の極性基をもつ合成 三分子膜はホスファチジルコリン型のグリセロリン脂質二分子膜にくらべて相転移熱, 転移エントロピ

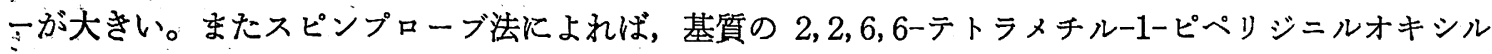
の二分子膜への取り込みはリン脂質膜では合成二分子膜のそれにくらべて最大 8.7 倍を示した。さらに 脂肪酸型プローブ剂を用いて緩和時間の測定から活性化エネルギーを求めた結果，アルキル鎖長または 不飽和結合の有無によって相違が認められた。コレステロールをこれらの二分子膜に混入すると相転移 は消隇し，基質の二分子膜への取り込みは阻害され緩和時間は大きくなる。

\section{1 緒 言}

細胞の内部組織において細胞膜, 核膜などに $50 \sim 100 \AA ̊$ の厚み をるつ二分子膜構造が存在することが知られており生体膜と総称 されている。二分子膜を構成する脂質分子は，二分子膜平面に沿 った側方拡散あるいは二分子膜平面の垂直方向での脂質分子の交 换 (フリップフロップ現象) など様々な分子運動が可能であり, きわめて流動性に富んでいる。現在ではこれらの分子運動にとも なら流動性の变化が生体膜の輸送機能などの発現に重要な意義を るつことが知られている。さらにここ数年, 生体膜の二分子膜構 造を形成するリン脂質と類似した両親媒性の構造をるつ化合物に る二分子膜形成能があることが知られるようになり, 合成二分子 膜として触媒性扣よび不斉場を利用した反応などへの応用あるい は様々な機能性を付与することがさかんに研究されている。しか し, これらの合成二分子膜の物性に関する研究は少ないが最近い くつかの報告がみられる2) 站。

そこで本研究では合成化合物としてジアルキルアンモニウム 塩, リン酸ジアルキルエステル塩, スルホコハク酸ジアルキルエ

熊本大学工学部合成化学科, 860 熊本市黒髮

** 熊本大学工学部工業化学科, 860 能本市黒髮

*** 九州大学工学部合成化学科, 812 福岡市箱崎

1) R, D. Kornberg, H. M. McConell, Biochemistry., 10, 1111(1971).

2) T. Kajiyama, Y. Hamada, F. Kumamaru, M. Takayanagi, Y. Okahata, T. Kunitake, Rept. Prog. Polym. Phys. Jpn., 21, 701(1978).

3) M. Kodama, M. Kuwabara, S. Seki, Thermochim. Acta, 50, 81(1981).

4) Y. Okahata, R. Ando, T. Kunitake, Ber. Bunsenges. Phys. Chem., 85, 789(1981).
ステル塩および天然リン脂質として卵黄レシチン, ジパルミトイ ルホスファチジルコリンを用いて超音波処理して，マルチラメラ 構造をもつ二分子膜を構成し2，その熱的物性，分子運動性に関 する基礎的研究を示差走査熱量分析法（以下 DSC 法と略記す る)，スピンプローブ法を用いて行なった。また生体膜系の二分 子膜の流動性や透過性を調整するといわれるコレステロールを合 成二分子膜に混入して，その影響について検討を行なった。

\section{2 実 験 方 法}

\section{1 二分子膜試料}

二分子膜試料としては, ジアルキルジメチルアンモニウム ロミド，リン酸ジアルキルナトリウム，スルホコハク酸ジアルキ ルエステル=ナトリウム塩 (以下それぞれ $2 \mathrm{C}_{n} \mathrm{~N} \oplus 2 \mathrm{C}_{1} \mathrm{Br} \odot$, $2 \mathrm{C}_{n} \mathrm{PO}_{4} \ominus \mathrm{Na} \oplus, 2 \mathrm{C}_{n} \mathrm{SO}_{3} \oplus \mathrm{Na}^{\oplus}$ と略記する $\left.{ }^{5)}\right)$, 卵黄レシチン (Panaborn の改良法 ${ }^{6}$ に準じて鵎卵から溶媒抽出精製し, 赤外吸 収スペクトル7により確認した), ジパルミイルホスファチジル コリン（以下 DPPC と略記する。試楽特級, シグマ社, 米国) を使用した。図1に分子式を示す。

\section{2 スピンプローブ剂}

$2,2,6,6$-テトラメチルー1-ピペリジニルオキシル $(2,2,6,6$ tetramethyl-1-piperidinyloxyl)，2-(10-カルボキシデシル)-2ヘキシル-4, 4-ジメチルー3-オキサゾリジニルオキシル (2-(10carboxydecyl)-2-hexyl-4, 4-dimethyl-3-oxazolidinyloxyl) (以 下それぞれ TEMPO，I $(10,5)$ と略記する。試薬特級, Syva 社,

5) T.Kunitake, Y. Okahata, K. Tamaki, F. Kumamaru, M. Takayanagi, Chem. Lett., 1977, 387.

6) 日本化学会編, “実験化学請座 23 (生物化学)”, 丸善 (1957) p. 491.

7）永井克孝, 野島王七, “脂質”, 朝倉書店（1973） p. 247 . 


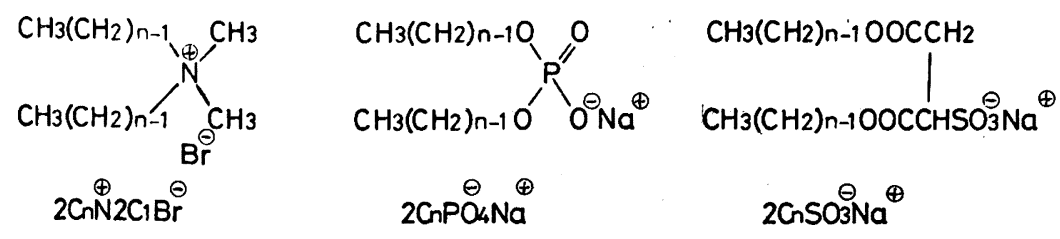

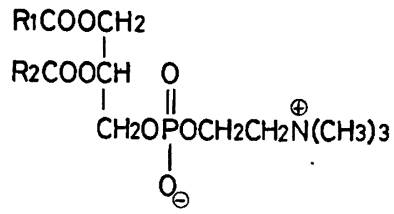

Egg yolk lecithin

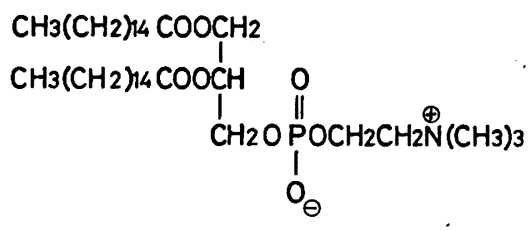

DPPC

Scheme 1 Molecular structures and abbreviations of the compounds used in this experiment<smiles>CC1(C)CCCC1(C)C</smiles>

TEMPO<smiles>CCC[C@@]1(CC(=O)O)OCC(C)(C)[C@@]1(C)CC(=O)O</smiles>

$I(10,5)$
Scheme 2 Molecular structures of the spin probe 米国）はそのまま使用した。図式 2 に分子式を示す。

\subsection{DSC 測定}

絶礼した二分子膜陚料を含水率の变化を抑えるため, 内径 4 $\mathrm{mm}$ の短いガラスサンプル管に約 $20 \mathrm{mg}$ 精科してその 10 倍量 の水とともに加之て密栓して含水率 $91 \mathrm{wt} \%$ の混合物とし，こ れを $60 \sim 70^{\circ} \mathrm{C}$ の湯浴に浸して 30 分間超音波処理して均一な分 散液を得た。放冷してからすばやく DSC 測定用ふた付きセルに 密封して熱量測定を行なった。装置は島津 $\mathrm{SC}-20$ 型を用い昇温 速度 $2.5^{\circ} \mathrm{C} / \mathrm{min}$ て測定した。吸熱量は単位モルあたりに换算し たェンタルピー变化 $\Delta H$ と相転移温度 $T_{\mathrm{c}}$ とから相転移での自 由エネルギーを 0 としエントロピー変化 $\Delta S$ として表わした。

$$
\Delta S=\Delta H / T_{\mathrm{c}}
$$

また，瞙の相転移をアルキル鎖の屈曲運動の增加，つまり炭 素-炭素結合のトランス形からゴーシュ形へのコンホメーション の変化とみなしてゴーシュ結合数を次式)で見積もった。

$$
\Delta S=\boldsymbol{k} \ln m, \quad m={ }_{n-2} C_{l} \cdot 2^{l}
$$

ここで, $\boldsymbol{k}$ は Bolzmann 定数, $n$ はアルキル鎖 1 本あたりの炭 素一炭素結合，lはゴーシュ結合数， $m$ は状態数を表わす。

\subsection{ESR 測定}

プロープ剤のアセトニトリル溶液をマイクロシリンジで内径 4 $\mathrm{mm}$ のガラスサンプル管に入れ軽く吸引して螾媒を除いた。つぎ 飞既知濃度 $(\mathrm{mg} / \mu \mathrm{l})$ の二分子膜試料のクロロホルム溶液から所 定量の二分子膜試料を加えて柽く吸引して溶媒を除いたのち，減 圧 (1〜 $5 \mathrm{mmHg})$ して溶媒を除去し，これに $0.1 \mathrm{~mol} / l \mathrm{HCl}-0.2$ $\mathrm{mol} \cdot \mathrm{dm}^{-3}$ トリス緩衝液 $(\mathrm{pH} 7.05 \sim 7.20)$ を所定量の二分子膜浱 度 $\left(3 \sim 10 \mathrm{mmol} \cdot \mathrm{dm}^{-3}\right)$ になるように加兄て密閉した。この混合 物を試料の $T_{\mathrm{c}}$ より約 $10^{\circ} \mathrm{C}$ 高い湯浴に浸して 1 時間超音波処理 することによって透明な二分子膜の分散液を得た。このようにし

8）木村初男，化学の領域，34，912(1980).

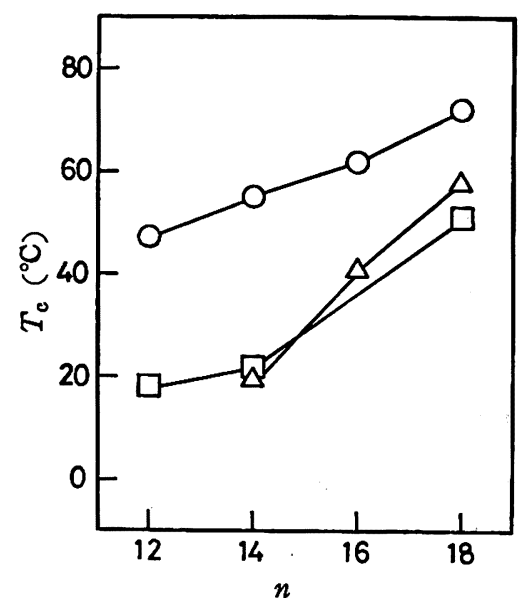

Fig. 1 Plots of the phase transition temperature $\left(T_{e}\right)$ versus number of the carbon atoms $(n)$ in alkyl chain

O : $2 \mathrm{C}_{n} \mathrm{PO}_{4} \ominus \mathrm{Na}^{\oplus}, \triangle$ : Diacylglycerophosphocholine, $\square: 2 \mathrm{C}_{n} \mathrm{~N}^{\oplus} 2 \mathrm{C}_{1} \mathrm{Br} \Theta$

て得られた二分子膜はマルチラメラ構造であることが電子顕微鏡 写真によって確かめられている2)。これを内径 $0.5 \mathrm{~mm}$ の毛細管 に密封して ESR 測定用試料とした。コレステロールの添加はク ロロホルム溶液として二分子膜試料添加と同時に行なった。プロ ーブ剤濃度は $0.1 \mathrm{mmol} \cdot \mathrm{dm}^{-3}$ 程度とし二分子膜への影響を少な くするように考慮した。測定は試料毛細管を測定用石英管に入 れ，熱電対により $0.5^{\circ} \mathrm{C}$ の精度で日本電子(株)製電子スピン共 鳴装置 (JESFEAX，X-バンド，磁場変調）を用いて行なった。

\section{3 実験結果および考察}

\section{1 ゲルー液晶相転移に関する DSC 測定結果}

二分子膜の熱的挙動のらち，二分子膜のゲル-液晶相転移にう いてはX線回折やスピンプローブ法からすでによく知られている

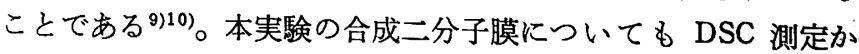
らゲルー液晶相転移が観察された。

図 1 は二分子膜の $T_{\mathrm{c}}$ をアルキル鎖炭素数に対してプロットし たものである。極性基の同じ系列では，アルキル鎖長が増すにし

9) D. M. Engelman, J. Mol. Biol., 47, 115(1967).

10) O. H. Griff th, ibid., 59, 77(1971). 
Table 1 Thermodynamic data for the membrane-water systcm at gel-liquid crystal phase transition

\begin{tabular}{|c|c|c|c|c|c|}
\hline Material & $\begin{array}{l}T_{\mathrm{c}} \\
\left({ }^{\circ} \mathrm{C}\right)\end{array}$ & $\begin{array}{l}\text { Endothermal } \\
\text { capacity } \\
\text { (cal } / g \text { ) }\end{array}$ & $\begin{array}{c}\text { Enthalpy } \\
\Delta H \\
\text { (kcal/mol) }\end{array}$ & $\begin{array}{c}\text { Entropy } \\
\Delta S \\
(\mathrm{cal} / \mathrm{mol} \cdot \mathrm{deg})\end{array}$ & $\begin{array}{c}\text { Number of gauche bonds } \\
\text { per one chain }\end{array}$ \\
\hline $2 \mathrm{C}_{12} \mathrm{~N}^{\oplus} 2 \mathrm{C}_{1} \mathrm{Br} \odot$ & 18 & 26.3 & 12.2 & 41.9 & 3.0 \\
\hline $2 \mathrm{C}_{18} \mathrm{~N}^{\oplus} 2 \mathrm{C}_{1} \mathrm{Br} \odot$ & 51 & 20.2 & 12.7 & 39.3 & 2.5 \\
\hline $2 \mathrm{C}_{12} \mathrm{PO}_{4} \ominus \mathrm{Na}^{\oplus}$ & 47 & 18.7 & 8.5 & 26.7 & $>3.8$ \\
\hline $2 \mathrm{C}_{18} \mathrm{PO}_{4} \ominus \mathrm{Na} \oplus$ & 72 & 17.4 & 10.0 & 29.1 & 3.8 \\
\hline $2 \mathrm{C}_{12} \mathrm{SO}_{3} \ominus \mathrm{Na}^{\oplus}$ & 28 & 18.0 & 10.0 & 33.2 & - \\
\hline DPPC & 41 & 7.8 & 6.0 & 19.0 & 1.5 \\
\hline
\end{tabular}

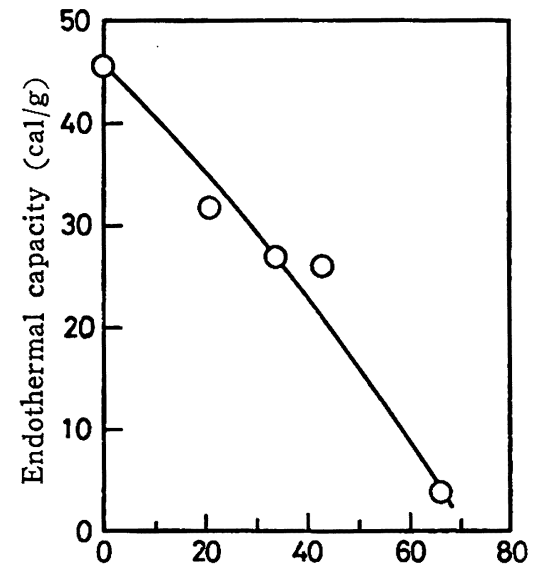

Mole fraction of cholesterol (mol\%)

Fig. 2 Dependence of the mole fraction of cholesterol for $2 \mathrm{C}_{18} \mathrm{~N}^{\oplus} 2 \mathrm{C}_{1} \mathrm{Br} \odot$ on the endothermal capacity at the phase transition temperature

たがって $T_{\mathrm{c}}$ が高温側ヘシフトすることがわかる。また同じアル キル鎖長をもつ二分子膜の $T_{\mathrm{c}}$ は極性基の構造によって影響さ れる。

表 1 はゲルー夜晶相転移における二分子膜の $T_{\mathrm{c}}$ および吸熱量 を示したものである。報告4)11) $T_{\mathrm{c}}$ 值と比較的よく一致してい る。合成二分子膜の $\Delta H$ および( 1 )式によって求められた $\Delta S$ が 生体系膜成分の DPPC 二分子膜のそれと比較して大きい值をと ることは注目される。これら二分子膜素材による吸熱量の相違は 二分子膜を構成するアルキル鎖長, 極性基の違いによる各種分子 間相互作用の差が寄与したものと考えられる。

(2)式から求めたゴーシュ結合数については, 合成二分子膜は リン脂質二分子膜の DPPC にくらべて約 2 倍の值を示した。脂 肪族炭化水素のゴーシュ結合 1 個の生成には約 $0.4 \mathrm{kcal}$ 程度の 熱量が必要とされるから, 相転移においてはこれらの合成二分子 膜には 2〜3kcal $/ \mathrm{mol}$ 程度のアルキル鎖による内部ェネルギー の增加があると考えられる。合成二分子膜の相転移に関して脂質 以外の物質の混入による影響を調べるために動物細胞に多く存在 するコレステロールを用いて，熱的物性におよぼす効果を検討し た。

図 2 は $2 \mathrm{C}_{18} \mathrm{~N} \oplus 2 \mathrm{C}_{1} \mathrm{Br} \odot$ とコレステロールのモル比を変化させ た場合の転移熱の変化を示したものであるが，コレステロールの 增加とともに転移熱が減少し $60 \mathrm{~mol} \%$ のコレステロール混入に

11) T. Kunitake, Y. Okahata, R. Ando, S. Shinkai, S. Hirakawa, J. Am. Chem. Soc., 102, 7877(1980).

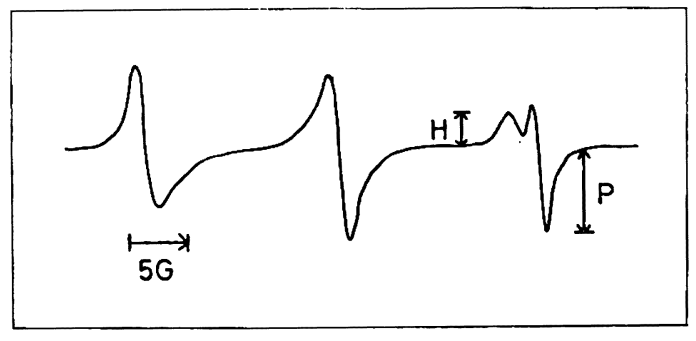

Fig. 3 ESR spectrum of TEMPO diffusing in the $2 \mathrm{C}_{18^{-}}$ $\mathrm{N}^{\oplus} 2 \mathrm{C}_{1} \mathrm{Br} \odot$ membrane

Concn.: $5 \mathrm{wt} \% 2 \mathrm{C}_{18} \mathrm{~N}^{\oplus} 2 \mathrm{C}_{1} \mathrm{Br}^{\ominus}$ aqueous dispersion Cholesterol content : 20 mol $\%$ for $2 \mathrm{C}_{18} \mathrm{~N}^{\oplus} 2 \mathrm{C}_{1} \mathrm{Br} \ominus$ Temp.: $60^{\circ} \mathrm{C}$

よって転移熱は０に近い值をとり相転移がほぼ見られなくなるこ とがわかる。このことは，DPPC二分子膜についてュレステロー ルが増加するとともに転移熱が減少し，等量になると転移が見ら れなくなるという Chapman らの結果 ${ }^{12)}$ と一致するものであり， コレステロールがゲル相における脂質間の配向をくずしているこ とを示唆している。

\section{2 スピンプローブ法による測定結果}

3.2.1 二分子膜の TEMPO の分配定数：極性・無極性の 2 相が共存する検体については，プローブが両相に分配されるとき にスペクトルのピークが二重に分裂することを利用してプローブ の両相中の分配率を求めることができる。

図 3 K $2 \mathrm{C}_{18} \mathrm{~N} \oplus 2 \mathrm{C}_{1} \mathrm{Br} \ominus$ 二分子膜の 水分散液中の TEMPO プ ローブの ESR スペクトルを示す。高磁場線が二重に分裂してい るが，その内側のピーク(ピーク高 $H)$ は二分子膜相に取り込ま れた TEMPO のシグナル, 外側のピーク (ピーク高 $P$ ) は水相 に溶けた TEMPO のシグナルである。このうち水相のシグナル はニトロキシドラジカルの還元剤で水溶性の L-アスコルビン酸 で系を処理すると消去できる。スペクトルの高さの比をつぎのよ らにとることで TEMPO の膜相への溶解度の分率をパラメータ 一化して $f$ 值として表わすことができ,

$$
f=\frac{H}{H+P}
$$

さらに TEMPO の膜相および水相の分配定数を $K$, 膜相およ び水相の体積を $V_{\mathrm{m}}, V_{\mathrm{w}}$ とすると

12) B. D. Ladbrooke, R. M. Williams, D. Chapman, Biochim. Biophys. Acta, 150, 333(1968). 


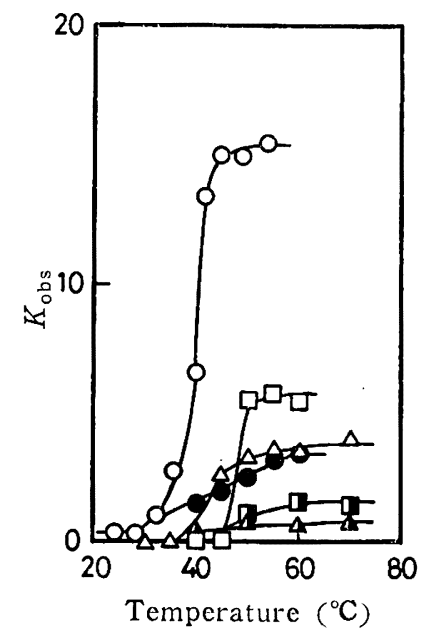

Fig. 4 Temperature dependence of the distribution coefficient $\left(K_{\text {obs }}\right)$

\begin{tabular}{|c|c|c|}
\hline & \multicolumn{2}{|c|}{ Cholesterol content } \\
\hline & 0 mol $\%$ & $20 \mathrm{~mol} \%$ \\
\hline $2 \mathrm{C}_{18} \mathrm{~N}^{\oplus} 2 \mathrm{C}_{1} \mathrm{Br} r^{\ominus}$ & $: \square$ & \\
\hline DPPC & $: \bar{O}$ & \\
\hline $2 \mathrm{C}_{12} \mathrm{PO}_{4} \oplus \mathrm{Na}^{\oplus}$ & $: \triangle$ & \\
\hline
\end{tabular}

Table 2 Calculated distribution coefficient $\left(K_{\mathrm{obs}}\right)$ of TEMPO in the membrane-water system

\begin{tabular}{lcr} 
Material & $\begin{array}{c}\text { Temperature of } \\
\text { measurement }\left({ }^{\circ} \mathrm{C}\right)\end{array}$ & $K_{\text {obs }}$ \\
\hline $2 \mathrm{C}_{12} \mathrm{~N} \oplus 2 \mathrm{C}_{1} \mathrm{Br} \odot$ & 25 & 6.6 \\
$2 \mathrm{C}_{18} \mathrm{~N} \mathrm{~N}^{\oplus} 2 \mathrm{C}_{1} \mathrm{Br}{ }^{\ominus}$ & 51 & 5.9 \\
$2 \mathrm{C}_{12} \mathrm{PO}_{4} \ominus \mathrm{Na}{ }^{\oplus}$ & 55 & 3.6 \\
Egg yolk lecithin & 45 & 16.0 \\
DPPC & 45 & 15.0
\end{tabular}

$$
f=\frac{K V_{\mathrm{m}} / V_{\mathrm{w}}}{1+K V_{\mathrm{m}} / V_{\mathrm{w}}}
$$

である ${ }^{13)}$ そここでこの逆数をとると

$$
\frac{1}{f}=1+\frac{1}{K} \cdot \frac{V_{\mathrm{w}}}{V_{\mathrm{m}}}=1+\frac{1}{K_{\mathrm{obs}}} \cdot \frac{W_{\mathrm{w}}}{\sigma_{\mathrm{w}}} \cdot \frac{\sigma_{\mathrm{L}}}{W_{\mathrm{L}}}
$$

ここで, $W_{\mathrm{w}}, W_{\mathrm{L}}$ および $\sigma_{\mathrm{w}}, \sigma_{\mathrm{L}}$ はおのおの水相, 膜相の重量 と密度である。膜相の密度はタンパク質の存在の少ない生体膜の

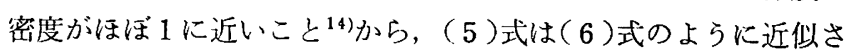
れる。

$$
\frac{1}{f}=1+\frac{1}{K_{\mathrm{obs}}} \cdot \frac{W_{\mathrm{w}}}{W_{\mathrm{L}}}
$$

(6)式から TEMPO の膜相と水相との分配定数 $K_{\mathrm{obs}}$ を求め た。 $2 \mathrm{C}_{18} \mathrm{~N} 22 \mathrm{C}_{1} \mathrm{Br} \ominus ， 2 \mathrm{C}_{12} \mathrm{PO}_{4} \ominus \mathrm{Na}$ および $\mathrm{DPPC}$ 二分子膜に おける TEMPO の分配定数の温度依存性は $T_{\mathrm{c}}$ 以下ではほとん ど 0 に等しく， $T_{\mathrm{c}}$ 付近で急激に大きくなり $T_{\mathrm{c}}$ 以上ではほぼ一 定の值で市った（図 4 参照）。 $T_{\mathrm{c}}$ 以上の温度で測定した各種二分 子膜系の TEMPO の $K_{\mathrm{obs}}$ は極性基による影響を受故るが，フ

13）日本生化学会編, “生化学実唤筷座 14 (生体膜)”, 東京化 骂同人 (1977) p. 51.

14）近戴化学工栄会縓, “膜(化学增刊 64)”, 化学同人 (1978) p. 23.

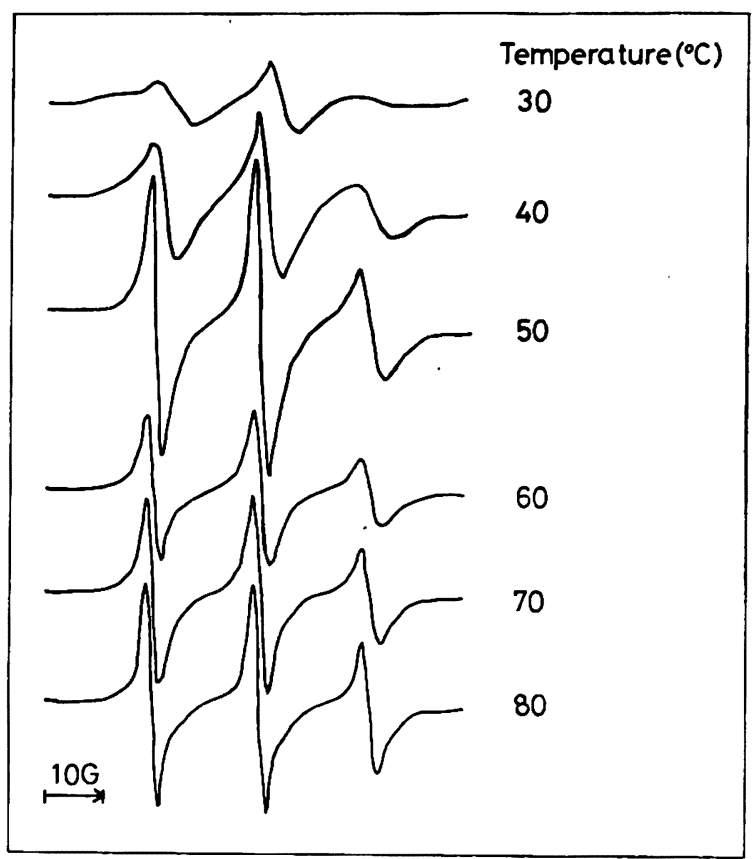

Fig. 5-a Temperature dependence of ESR spectra of 2-(10-carboxydecyl)-2-hexyl-4,4-dimethyl-3-oxazolidinyloxyl diffusing in the $2 \mathrm{C}_{18} \mathrm{~N}^{\oplus} 2 \mathrm{C}_{1} \mathrm{Br} \odot$ membrane $2 \mathrm{C}_{18} \mathrm{~N}^{\circledast} 2 \mathrm{C}_{1} \mathrm{Br} \odot: 6.0 \times 10^{-3} \mathrm{~mol} / l$

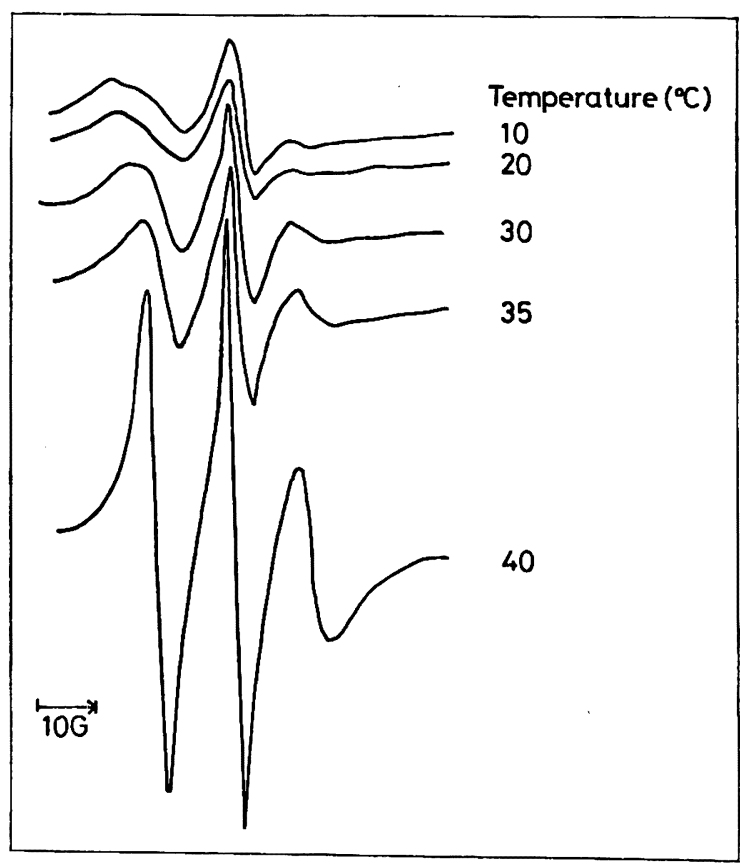

Fig. 5-b Temperature dependence of ESR spectra of 2-(10-carboxydecyl)-2-hexyl-4,4-dimethyl-3-oxazolidinyloxyl diffusing in the DPPC membrane

DPPC : $5 \times 10^{-3} \mathrm{~mol} / l$

ルキル鎖長の影響は小さい（表 2 参照）。また二分子膜にコレス テロールを $20 \mathrm{~mol} \%$ 混入したときの TEMPO の $K_{\mathrm{obs}}$ の変化 灾図 4 中に示した。2 種の合成二分子膜は DPPC 二分子膜と同 栐, $T_{\mathrm{c}}$ 付近での $K_{\mathrm{obs}}$ の立ち上がりは娍少し，コレステロール 


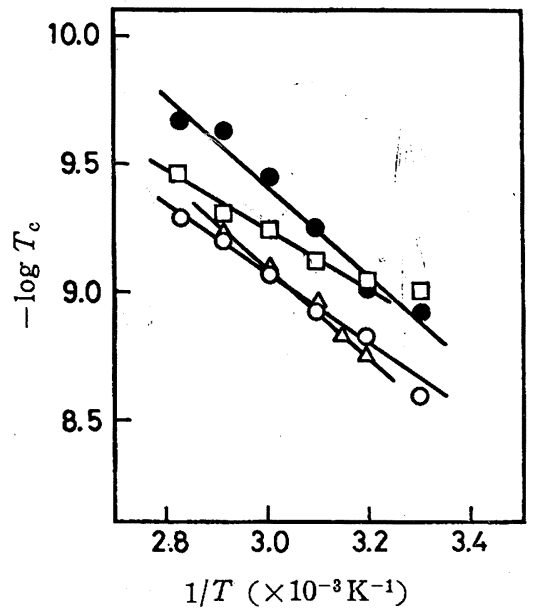

Fig. 6 Arrhenius plots of correlation time for the spin probed membrane with 2-(10-carboxydecyl)-2hexyl-4, 4-dimethyl-3-oxazolidinyloxyl

$\square: 2 \mathrm{C}_{12} \mathrm{~N} \oplus 2 \mathrm{C}_{1} \mathrm{Br} \odot$, $: 2 \mathrm{C}_{18} \mathrm{~N}^{\oplus} 2 \mathrm{C}_{1} \mathrm{Br} \odot$

$\mathrm{O}$ : Egg yolk lecithin, $\triangle$ : DPPC

による TEMPO の膜内への取り込みの阻害効果が顕著であり, 合成二分子膜はりン脂質二分子膜にくらべて TEMPO の取り込 み能力が小さいことがわかる。

3.2.2 脂肪酸型プローブによる二分子膜の分子運動性 : 二分 子膜のアルキル鎖部分の流動性に関する情報を得るために二分子 膜と類似の分子構造をもつ脂肪酸型プローブを用いた。図 5-a, b はそれぞれ $2 \mathrm{C}_{18} \mathrm{~N}^{\oplus} 2 \mathrm{C}_{1} \mathrm{Br} \odot, \mathrm{DPPC}$ 二分子膜をプローブ $\mathrm{I}(10,5)$ でプローブしたときの ESR スペクトルである。

両二分子膜とも $T_{\mathrm{c}}$ 付近からスペクトルは強度の強い等方的な 鋭い3本線スペクトルに移行するのが観察される。水相のプロー ブに起因した副次的な小さなスペクトルはいずれの場合も観察さ れなかった。一方, コレステロールを混入した場合, 合成二分子 膜系に沶いては温度に関係なく ESR スペクトルは水相に存在す るプローブに起因した鋭い等方的なものが得られ，コレステロー ルは, プローブ I $(10,5)$ に対するいちじるしい排除効果を生じ た。Kivelson の式 $(7)$ 式に準じてこのプローブのアルキル鎖部

15) D. Kivelson, J.Chem. Phys., 33, 1904(1960).
の運動の緩和時間 $\tau_{c}$ (回転相関時間) を求めた ${ }^{15)} 。$

$$
\tau_{\mathrm{c}}=\left\{\left(\frac{h_{0}}{h_{+1}}\right)^{1 / 2}+\left(\frac{h_{0}}{h_{-1}}\right)^{1 / 2}-2\right\} \frac{4 \pi \sqrt{3}}{b^{2}} \cdot W_{0}
$$

ここで， $W_{0}$ は中央ピークの線幅， $h_{+1}, h_{0}, h_{-1}$ は低磁場侧か ら 3 本線のそれぞれのピークの高さ，bはプローブの種類によっ て決まる定数を表わす。種々の二分子膜について $\tau_{\mathrm{c}}$ に関する Arrhenius プロットを図6に示した。活性化エネルギーはいずれ の二分子膜についても 6〜 $8 \mathrm{kcal} / \mathrm{mol}$ 程度である。とくにアル キル鎖長が短い $2 \mathrm{C}_{12} \mathrm{~N}^{\oplus} 2 \mathrm{C}_{1} \mathrm{Br} \ominus$ 二分子膜拉よびアルキル鎖長中 に二重絬合が含まれる卵黄レシチン二分子膜では活性化ェネルギ 一は小さい。プローブの動きはそれが存在する環境に対応してい るから,これらの膜の疎水性部分は流動性に富んでいることが示 唆される。

\section{4 結論}

本研究では数種の合成二分子膜を卵黄レシチンおよび DPPC 二分子暯と対比しながら DSC 法, スピンプローブ法を用いて二 分子膜の熱的物性および運動性を検討した。

（1） DSC 测定から，ジアルキルアンモニウム塩，リン酸ジ アルキルェステル塩，スルホコハク酸ジアルキルェステル塩型合 成二分子膜はホスファチジルコリン型のグリセロリン脂質二分子 膜にくらべて, 相転移での吸熱量, 転移エントロピーの值が大き w。

（2）基質として用いたプローブ剤 TEMPO の二分子膜への 取り込みは合成二分子膜で非常に小さく，リン脂質二分子膜は合 成二分子膜のそ机にくらべて最大 8.7 倍にもおよんだ。さらに基 質として脂肪酸型プローブ剂 $\mathrm{I}(10,5)$ を用いて分子運動の緩和 時間を測定し活性化エネルギーを求めた結果，アルキル鎖の鎖長 が短いもの，卵黄レシチンのようにアルキル鎖長が長いにもかか わらずその中に不飽和結合を含んでいる系では活性化エネルギー は小さく，膜の柾水部は柔軟性に富んでいることが示唆された。

（3）二分子膜にコレステロールを混入した系では，コレステ ロールの濃度が增すと相転移熱は娍少し，プローブの緩和時間が 大きくなる。また同時に基質の二分子膜中への取り込みに関する 阻書効果が顕著に現われるが，この効果は合成二分子膜ではとく にいらじるしい。

終りに本研究に関し，種々御討議いただいた西田治男，宇都久 美子両氏に深く感謝致します。 


\title{
Evaluation of the Function of Synthetic Bimolecular Membranes and Phospholipids by Spin-Probe Method and Differential Scanning Calorimetry
}

\author{
Shuichi Honda, The late Naoshi Kusumoto**, Chuichi Hirayama*, \\ Toyoki Kunitake*** and Yoshiaki Motozato \\ Department of Synthetic Chemistry, Faculty of Engineering, \\ Kumamoto University; Kurokami, Kumamoto-shi 860 Japan \\ ** Department of Industrial Chemistry, Faculty of Engineering, \\ Kumamoto University; Kurokami, Kumamoto-shi 860 Japan \\ *** Department of Organic Synthesis, Faculty of Engineering, \\ Kyushu University; Hakozaki, Fukuoka-shi 812 Japan
}

The amount of heat absorption of synthetic bimolecular membranes and phospholipids, which contained various polar groups and alkyl chain of different length at gel-(liquid crystal) phase transition temperature, the movements of alkyl chain part of the membranes and the differences of incorporation of probe into the membranes were studied by differential scanning calorimetry and the spin-probe method. The variation of physical properties of the bimolecular membranes at incorporation with cholesterol into the membranes was also investigated. According to the measurements of differential scanning calorimetry, the synthetic bimolecular membranes containing ammonium salt, phosphate and sulfonate as the polar groups had larger amounts of heat absorption and transition entropy than phosphoglycerides bimolecular membrane of phosphatidylcholine type. The incorporation of 2,2,6,6-tetramethyl-1-piperidinyloxyl used as a spin-probe into the phospholipids membranes was 8.7 times higher than those of the synthetic bimolecular membranes. The activation energy, obtained from the measurement of relaxation time by molecular movements using spin-probe of aliphatic acid type, was remarkably influenced by the length of alkyl chains and existence of the unsaturated bond. By the incorporation of cholesterol into the bimolecular membranes, phase transition was eliminated and the incorporation of the probe into the bimolecular membranes was disturbed. These phenomena were interpreted on the basis of a variation of fluidity of the bimolecular membranes. 